\title{
Erythema Nodosum: A Practical Approach and Diagnostic Algorithm
}

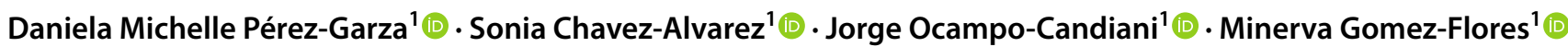

Accepted: 5 February 2021 / Published online: 8 March 2021

(c) The Author(s), under exclusive licence to Springer Nature Switzerland AG part of Springer Nature 2021

\begin{abstract}
Erythema nodosum is the most common form of panniculitis and is characterized by tender erythematous nodules mainly in the lower limbs on the pretibial area. The exact cause of erythema nodosum is unknown, although it appears to be a hypersensitivity response to a variety of antigenic stimuli. Although the etiology is mostly idiopathic, ruling out an underlying disease is imperative before diagnosing primary erythema nodosum. Erythema nodosum can be the first sign of a systemic disease that is triggered by a large group of processes, such as infections, inflammatory diseases, neoplasia, and/or drugs. The most common identifiable causes are streptococcal infections, primary tuberculosis, sarcoidosis, Behçet disease, inflammatory bowel disease, drugs, and pregnancy. We propose a diagnostic algorithm to optimize the initial work-up, hence initiating prompt and accurate management of the underlying disease. The algorithm includes an initial assessment of core symptoms, diagnostic work-up, differential diagnosis, and recommended therapies. Several treatment options for the erythema nodosum lesions have been previously reported; nevertheless, these options treat the symptoms, but not the triggering cause. Making an accurate diagnosis will allow the physician to treat the underlying cause and determine an optimal therapeutic strategy.
\end{abstract}

\section{Key Points}

Erythema nodosum is mainly idiopathic, although it can be the first sign of a systemic disease.

Several conditions have been described as triggering causes of erythema nodosum; thus, an optimized costeffective initial work-up is necessary.

An algorithm that includes an initial assessment of core symptoms, diagnostic work-up, differential diagnosis, and recommended therapies can lead to a prompt and accurate diagnosis and an optimal therapeutic strategy.

Minerva Gomez-Flores

minervagomezmx@yahoo.com.mx

1 Department of Dermatology, Universidad Autonoma de Nuevo Leon, University Hospital "Dr. José Eleuterio González”, Avenida Francisco I. Madero y Avenida Gonzalitos S/N, Colonia Mitras Centro, 64460 Monterrey, Nuevo León, Mexico

\section{Definition}

Panniculitis is a heterogeneous group of inflammatory processes that affect the subcutaneous cellular tissue. They are classified into two groups: (1) lobular or (2) septal panniculitis. Erythema nodosum (EN) is the most common form of panniculitis and it is the prototypic septal panniculitis [1]. Erythema nodosum was first described by Robert Willan in 1798 [2]. Historical data concerning EN date back to 1762 to a prior possible description of an EN lesion in a letter from Wolfgang Amadeus, Mozart's father, which could be the first record of this disease [3]. This review aims to evaluate the current literature of the triggering factors and treatment options for EN to propose an easy-to-follow diagnostic algorithm. A search of the literature was performed in PubMed. Keywords used included: "erythema nodosum" and any of the following: "etiology, Behçet's disease, sarcoidosis, tuberculosis, inflammatory bowel disease, streptococcal infection, drugs or vaccines, malignancies or cancer," "epidemiology," "therapy or treatment," "diagnosis," "histopathology," and "pathophysiology." The search was limited to articles published from 1950 to 2020. Titles and abstracts in English and Spanish were reviewed for eligibility. References of selected relevant articles were scanned, and papers from these sources were also included. 


\section{Epidemiology}

The incidence of EN varies according to the triggering factor and its ethnic, racial, and geographic differences. In north-western Spain, the annual incidence rate of biopsyproven EN for the population aged 14 years and older was 52 cases/million and the incidence was higher in the first half of the year when streptococcal infections are more frequent [4]. In Egypt, the foremost etiology reported between 1994 and 2002 was primary tuberculosis (TB) [5], while in Spain, sarcoidosis was the most frequent identified etiology [4]. Among adults, this condition affects women more frequently, with a male:female ratio of 1:5 [6]. In children, there is no difference regarding sex, up to the age of 12 years [7]. The maximum number of incidences occurs between the second and third decades although it can occur at any age $[8,9]$.

\section{Pathogenesis}

Erythema nodosum is considered a hypersensitivity response to a variety of antigenic stimuli. It has been proposed that EN may be the result of the formation of immune complexes and their deposition in the venules of the septae of the subcutaneous fat [10]. Evidence of circulating immune complexes in early lesions supports the suggestion that the antigen, antibody, and complement play a significant role in the pathogenesis and circulating immune complexes may contribute to tissue injury [11, 12]. However, some authors have reported a lack of circulating immune complexes in uncomplicated EN, and a type IV delayed hypersensitivity reaction has been proposed [13]. Several adhesion molecules and inflammatory mediators are involved in the development of the lesions. Expression of adhesion molecules, such as E-selectin, P-selectin, platelet endothelial cell adhesion molecule, vascular cell adhesion molecule-1, and intercellular adhesion molecule-1, on endothelial cells in patients with EN has been observed [14]. Early lesions are characterized by a neutrophilic inflammatory infiltrate in which activated neutrophils might cause oxidative tissue damage and inflammation owing to the production of reactive oxygen intermediates $[10,15]$. High levels of cytokines and growth factors, mainly involved in neutrophil recruitment and activation, have been reported both in the skin (mainly interleukin [IL]-6, IL-8, IL-12, interferon- $\gamma$, granulocyte colony-stimulating factor and monocyte chemoattractant protein-1) and serum (mainly IL-6, IL-8, IL-12, tumor necrosis factor- $\alpha$, interferon- $\gamma$, granulocyte colony-stimulating factor, and monocyte chemoattractant protein-1) of patients with EN [16]. Increased acute-phase reactants have been detected in patients with EN [12].

\section{Clinical Presentation}

The clinical course of EN is characterized by an acute onset of sensitive and erythematous nodules and plaques of $1-6 \mathrm{~cm}$ in diameter (Fig. 1a). Lesions are bilateral and symmetric, typically distributed on the distal lower extremities of the pretibial areas, although lesions can also involve the ankles, thighs, and forearms. Erythema nodosum is generally self-limited and resolves within 1-6 weeks by turning from a bright red to a yellow-brown or green-bluish discoloration, resembling bruises (Fig. 1b). These bruise-like evolution lesions are known as "erythema contusiformis" [10]. Coexistence of lesions in different stages of the evolution can be seen in the same patient. The nodules heal without ulceration, scarring, or atrophy, and recurrences are not uncommon $[1,10,17]$.

The skin lesions are frequently accompanied by systemic symptoms, such as fever, malaise, headache, gastrointestinal complaints (such as abdominal pain, vomiting, and diarrhea), cough, lymphadenopathy, weight loss, and arthralgia, mainly in the ankles and knees $[18,19]$. Some of these findings might be suggestive of EN secondary to a systemic disease, and these findings can provide important diagnostic clues.

The diagnosis is usually made in a characteristic clinical scenario and is easily distinguished from other nodular lesions. However, it should be confirmed by a deep incisional or excisional biopsy with a generous portion of subcutaneous fat. Once the pathological diagnosis has been made, the real challenge is the identification of the underlying etiology of EN, if present, before considering it idiopathic.

\section{Histologic Findings}

Erythema nodosum shows characteristic features of a predominantly septal panniculitis without vasculitis (Fig. 2a). Early lesions present with hemorrhage and edematous septa with a prominent mixed inflammatory infiltrate consisting of lymphocytes, histiocytes, eosinophils, and numerous neutrophils, infiltrating from the septa to the periphery of the adjacent lobules [20]. Late lesions show effacement of the lobules with fibrotic and thickened septa infiltrated by lymphocytes, histiocytes, multinucleated giant cells, and just a few neutrophils (Fig. 2b). The radial Miescher's granulomas consist of small collections of histiocytes arranged around a central star-shaped cleft. This is a relatively specific but not pathognomonic feature. Small- and even medium-sized vasculitis has occasionally been reported [21]. 
Fig. 1 Clinical features of erythema nodosum (EN). a Erythematous tender nodules bilaterally on the shins. b Bruise-like appearance "erythema contusiformis"
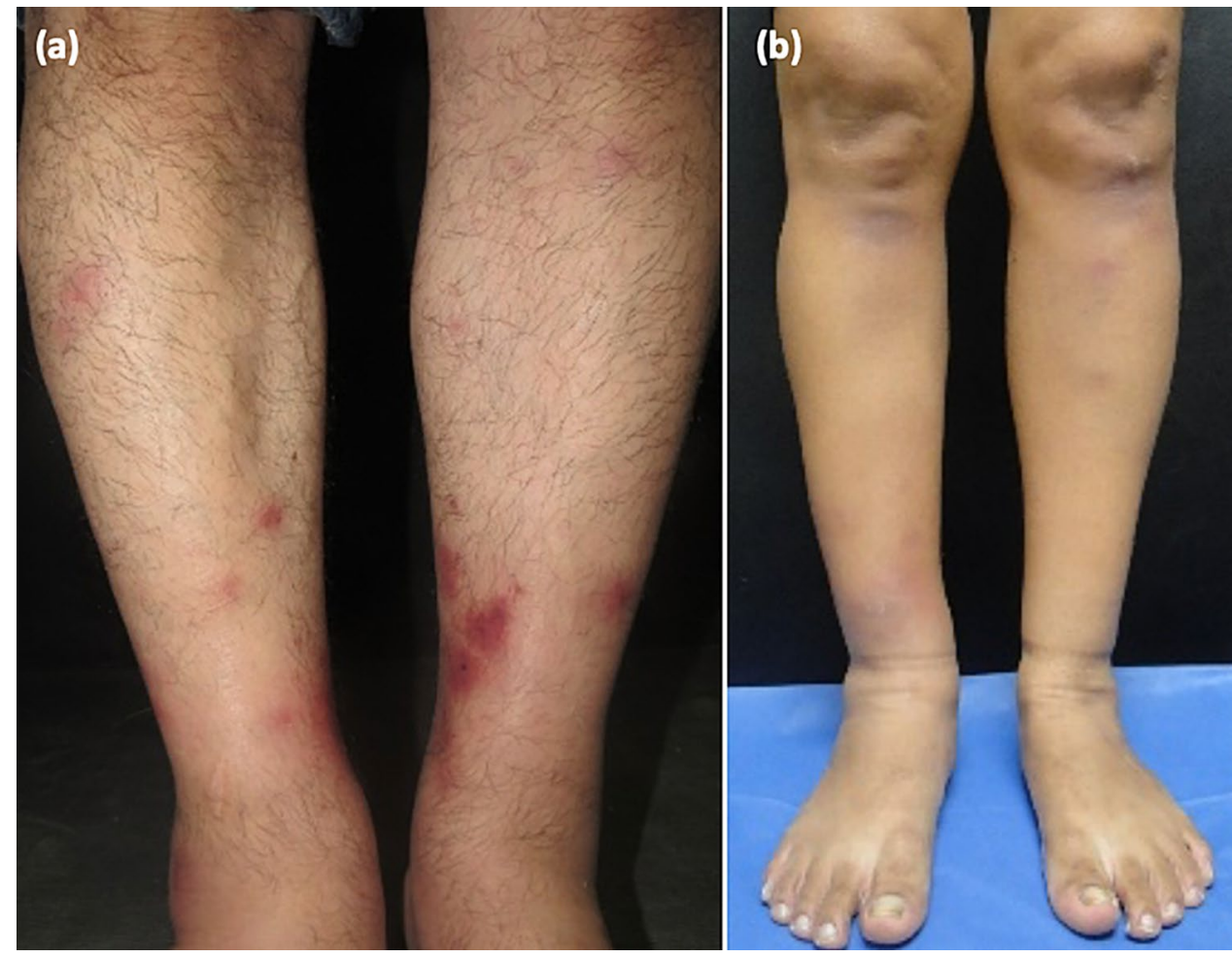

Fig. 2 Erythema nodosum (EN) histopathological features. Hematoxylin and eosin staining. a A predominantly septal panniculitis, at $\times 5$ magnification. b Lymphohistiocytic infiltrate with the presence of neutrophils and giant multinucleated cells at $\times 100$ magnification

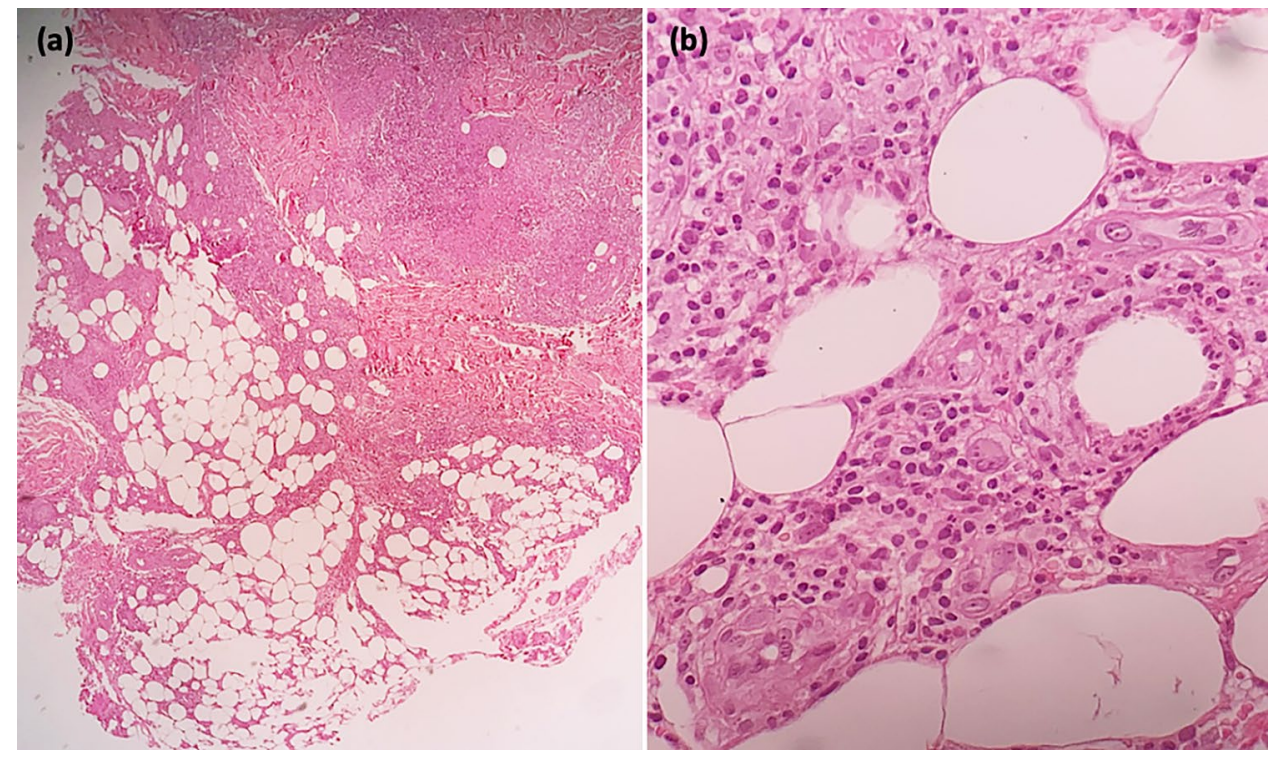

\section{Etiology}

The etiology varies according to the affected population, the geographical area, and the seasonal period, although according to the literature $32-72 \%$ of EN cases remain with an unknown etiology [4, 19, 22]. Erythema nodosum may be the first sign of a systemic disease, triggered by a large group of processes, such as infections, inflammation, neoplasias, and/or drugs (Table 1). The most common identifiable causes are streptococcal infections, primary TB, sarcoidosis, Behçet disease, drugs, pregnancy, and inflammatory bowel disease [19].

\subsection{Behçet Disease}

Patients diagnosed with Behçet disease present with EN lesions in about $44 \%$ of the cases, with EN being the initial manifestation of the disease in up to $5.7 \%$ of the cases [23]. Several diagnostic criteria have been proposed for Behçet 
Table 1 Etiologies of erythema nodosum [1, 9, 10, 93]

\begin{tabular}{|c|c|}
\hline \multicolumn{2}{|l|}{ Etiology } \\
\hline Primary & Idiopathic \\
\hline \multicolumn{2}{|l|}{ Secondary } \\
\hline \multicolumn{2}{|l|}{ Infections } \\
\hline Bacterial & $\begin{array}{l}\text { Beta-hemolytic Streptococcus, Staphylococcus, Escherichia coli, Klebsiella pneumoniae, Pseudomonas aeruginosa, Myco- } \\
\text { bacterium tuberculosis, atypical mycobacteria, yersiniosis, salmonellosis, shigellosis, brucellosis, rickettsiosis, leptospi- } \\
\text { rosis, tularemia, Bartonella henselae, syphilis, leprosy, Borrelia burgdorferi, meningococcemia, gonorrhea, chancroid, } \\
\text { Campylobacter spp., Chlamydia pisttaci, Corynebacterium diphteriae, Cutibacterium acnes, Moraxella cataralis, Pasteur- } \\
\text { ella pseudotuberculosis }\end{array}$ \\
\hline Viruses & $\begin{array}{l}\text { Infectious mononucleosis, hepatitis B and C, cytomegalovirus, herpes simplex, parvovirus B19, HIV, measles, varicella, } \\
\text { poxvirus (milker's nodule and Orf disease), Coronavirus Disease } 2019\end{array}$ \\
\hline Fungal & $\begin{array}{l}\text { Coccidioidomycosis, blastomycosis, histoplasmosis, sporotrichosis, nocardiosis, mucormycosis, aspergillosis, dermatophy- } \\
\text { tosis (Trichophyton spp.) }\end{array}$ \\
\hline Parasites & $\begin{array}{l}\text { Amebiasis, giardiasis, toxoplasmosis, taeniasis, ascariasis, hydatidosis, trichomoniasis, sparganum larvae, hookworm infes- } \\
\text { tation }\end{array}$ \\
\hline Systemic diseases & $\begin{array}{l}\text { Sarcoidosis, inflammatory bowel disease, celiac disease, colon diverticulosis, Behçet disease, Reiter syndrome, systemic } \\
\text { lupus erythematosus, antiphospholipid syndrome, rheumatoid arthritis, ankylosing spondylitis, Takayasu arteritis, Berger } \\
\text { disease, panarteritis nodosa, Wegener granulomatosis, Sweet syndrome, adult Still disease, acne fulminans, Sjögren syn- } \\
\text { drome, IgA nephropathy, chronic active hepatitis, granulomatous mastitis }\end{array}$ \\
\hline Drugs & $\begin{array}{l}\text { Penicillin, amoxicillin, ampicillin, cephalosporins, ciprofloxacin, sulfonamides, sulfonylureas, cotrimoxazole, streptomycin, } \\
\text { minocycline, nitrofurantoin, bromides and iodides, oral contraceptives, progesterone, gold salts, hydantoin, carbamaz- } \\
\text { epine, ACE inhibitors, ARBs, proton pump inhibitors, leukotriene inhibitors, aromatase inhibitors, granulocytic colony- } \\
\text { stimulating factors, fluoxetine, among others. Vaccines (tetanus, diphtheria, and acellular pertussis, BCG, hepatitis B, } \\
\text { human papillomavirus, malaria, rabies, smallpox, typhoid, and cholera) }\end{array}$ \\
\hline Malignancies & $\begin{array}{l}\text { Hodgkin and non-Hodgkin lymphoma, leukemia, sarcoma, pelvic carcinoma, carcinoid tumor, renal, cervix, gastric, colo- } \\
\text { rectal, pulmonary, hepatocellular, and pancreatic carcinoma }\end{array}$ \\
\hline Pregn & \\
\hline
\end{tabular}

$A C E$ angiotensin-converting enzyme, $A R B s$ angiotensin II receptor blockers, $H I V$ human immunodeficiency virus, $\operatorname{Ig} A$ immunoglobulin A

disease, and in the International Study Group International Criteria for Behçet's Disease, EN is included as a criterion [24]. Based on the histopathology, two forms of presentation are found: (1) the EN type with the typical septal panniculitis pattern in $27 \%$ of these cases and with a possible association with mild symptoms and (2) an EN-like with a lobular-mixed panniculitis pattern and vasculitis, representing $73 \%$ of cases, with an apparent association with severe disease [25].

\subsection{Inflammatory Bowel Disease}

Inflammatory bowel disease (IBD) can present as ulcerative colitis or as Crohn's disease. In addition to the gastrointestinal symptoms, up to $40 \%$ of these patients can have a variety of extraintestinal manifestations [26]. Erythema nodosum occurs in $4-15 \%$ of patients with Crohn's disease and in $3-10 \%$ of patients with ulcerative colitis [27, 28], with a female predilection $[29,30]$.

\subsection{Sarcoidosis}

In sarcoidosis, the most common skin lesion is EN [31]. Löfgren syndrome, an acute presentation of sarcoidosis, is characterized by EN, bilateral hilar lymphadenopathy, and fever. In conjunction with the EN lesions, patients can have periarticular ankle inflammation and papular lesions on the knees and elbows [17]. Diagnosis of sarcoidosis is usually made when clinical and radiological data are confirmed by a tissue biopsy (noncaseating granulomas) [32].

\subsection{Infections}

Erythema nodosum can present as a reactive cutaneous manifestation of infections, such as bacterial, viral, fungal, and protozoal.

\subsubsection{Streptococcal Infection}

After a pharyngeal streptococcal infection, skin lesions appear in about 2-3 weeks [10]. A throat culture, a rapid antigen Streptococcus test, or antistreptolysin O titers should be ordered when this etiology is suspected [33]. The antibody response is first seen during the second or third week of the acute episode and usually peaks in 4-5 weeks. Pharyngeal culture is still the gold standard for documenting the presence of group A $\beta$-hemolytic Streptococcus in these 
patients. Leukocytosis with neutrophilia and mild normochromic anemia can also occur [34].

\subsubsection{Tuberculosis}

In some developing countries in which the prevalence of TB is high, Mycobacterium tuberculosis infection is a contributing etiologic factor in EN development. A Chinese study reported a positive polymerase chain reaction analysis and interferon- $\gamma$-release assay in $30.4 \%$ and $59.4 \%$ of patients with EN, respectively [35]. Furthermore, another study suggests that EN among patients with M. tuberculosis infection is common, and EN appears to be a strong predictor or an early symptom of TB. Almost $50 \%$ of individuals with EN were diagnosed with TB within 1 month of their EN diagnoses, thus patients should be examined carefully and followed closely [36]. Chest radiography, sputum acidfast bacilli smear, mycobacterial culture, and nucleic acid amplification testing should be obtained to rule out pulmonary TB. Additionally a tuberculin skin test or interferon- $\gamma$ release assay should be performed [37]. These studies are mandatory in endemic regions. Furthermore, infection with an atypical mycobacteria species has been associated with EN [10].

\subsubsection{Other Infections}

Among other leading bacterial infections are Salmonella enteritidis, Salmonella typhimurium, Campylobacter jejuni, Yersenia enterocolitica, Mycoplasma, and Bartonella [38, 39]. Fungal infections, such as coccidioidomycosis [40] blastomycosis [41], and histoplasmosis [42], have been implicated in EN development. Patients' geographical locations and history of travel to these mycosis-endemic regions can provide diagnostic clues. An association between Coronavirus Disease 2019 and EN has been recently reported [43, 44]. Other infections that can develop EN are summarized in Table 1.

\subsection{Drugs and Vaccines}

Drugs are another frequent etiologic factor of EN and have been identified as the cause of EN in $2.9-5 \%$ of patients [4, $19,45]$. Sulfonamides, bromides, and oral contraceptives are the most commonly associated medications [10]. Some vaccines, such as tetanus, diphtheria, and acellular pertussis, BCG, hepatitis B, human papillomavirus, malaria, rabies, smallpox, typhoid, and cholera have been associated with subsequent development of EN [46]. All patients should be carefully questioned about recent medications or vaccines.

A role for different hormones in the development of EN has been described. Pregnancy represents the etiologic cause in $2-6 \%$ of patients $[6,19,45]$. Oral contraceptive pills and aromatase inhibitors are associated with EN development $[47,48]$.

\subsection{Malignancies}

An underlying malignancy can be responsible for EN symptoms in patients with unexplained EN and constitutional symptoms. Hematologic malignancies (leukemia and lymphoma) are most frequently associated with EN lesions, [49-52] and more rarely, solid neoplasms (lung, colon, cervix, hepatic, pancreatic, parathyroid, and carcinoid tumors) have been implicated [53-59]. In some cases, EN lesions indicate disease relapse [60]. Radiation can precipitate $\mathrm{EN}$, this must be taken into account in patients undergoing this treatment [61-63]. Patients with recurrent EN or poor response to conventional treatments should be investigated for an underlying malignancy.

\section{Diagnostic Assessment}

Because of the extensive number of possible etiologic processes, the diagnostic approach must be cost effective to initiate a specific treatment. Not all patients may need an extensive work-up, this will allow a cost reduction. Investigations should be tailored to diseases suspected from a careful history and physical examination. Systemic symptoms or altered laboratory test results favor secondary EN [5]; however, in symptomatic patients without a disease-specific clinical finding, a complete work-up must be performed to rule out a severe disease. This examination can lead to early diagnosis and prompt treatment, thus preventing the progression of a serious or life-threatening illness.

Diagnosis of EN is based on clinical presentation and histopathological findings. To identify the underlying cause, the initial work-up must contain a detailed medical history and physical examination. Paraclinical studies including a laboratory work-up and radiologic imaging studies might be necessary. We propose a diagnostic algorithm (Fig. 3) to assist clinicians in making an accurate and timely diagnosis to initiate appropriate treatment for the underlying condition.

The initial diagnostic work-up should be aimed at identifying common etiologies. Interrogation for disease-specific and non-specific symptoms, such as fever, fatigue, malaise, weight loss, organ-specific symptoms, and any recently used drugs, is necessary. Laboratory tests and imaging must be guided by the clinical findings, the choice of testing should be based on the history and physical examination. However, the etiology may vary depending on other factors such as the race and geographic location of the patient (Table 2), these factors also determine the laboratory tests and imaging studies that must be requested. Based on what has been published in the literature and taking into account the most 


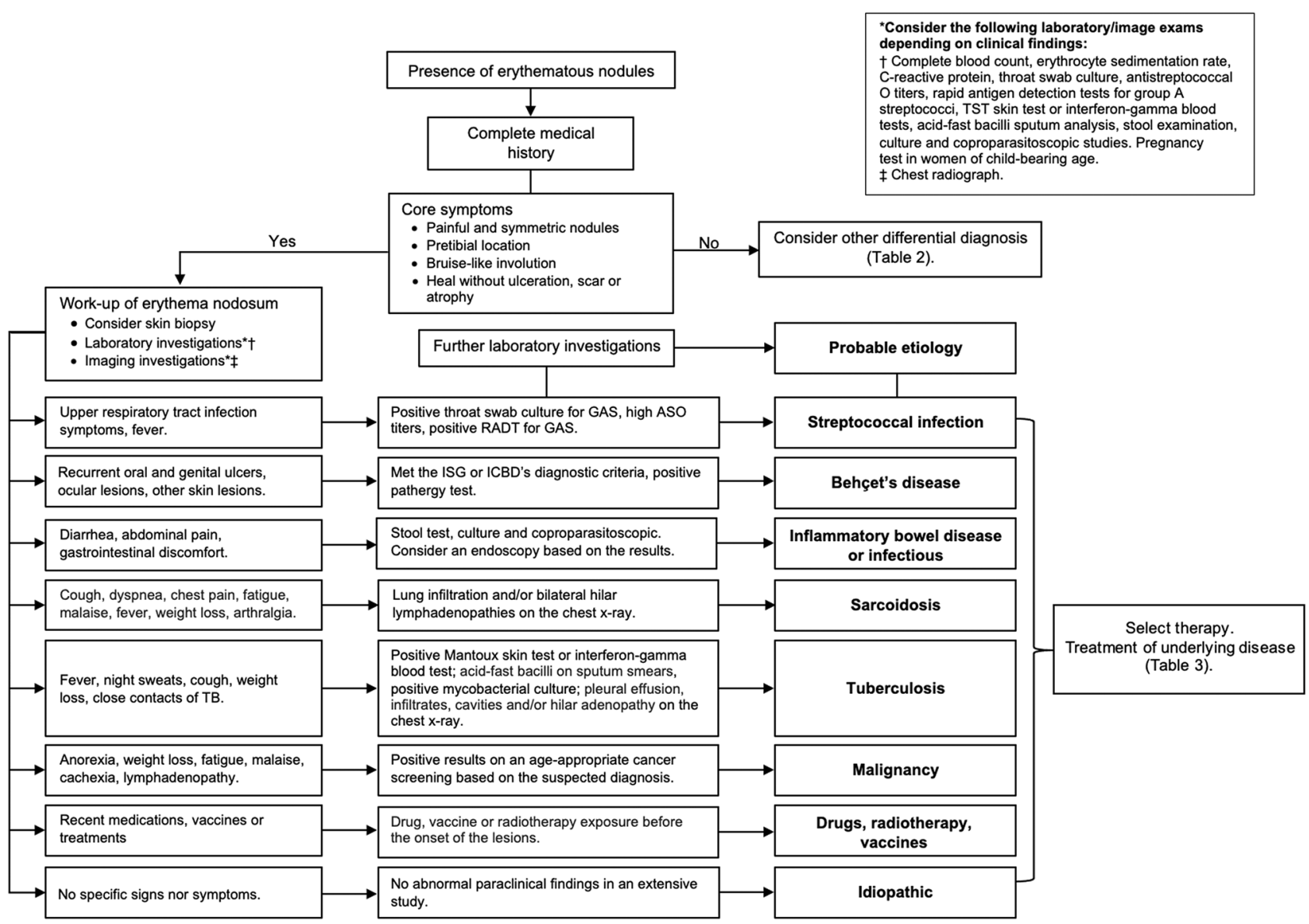

Fig. 3 Approach to the diagnosis of patients with erythema nodosum. ASO antistreptococcal O titers, GAS group A streptococci, ICBD International Criteria for Behçet's Disease, ISG International Study Group, RADT rapid antigen detection tests, $T B$ tuberculosis

frequently reported etiological factors of EN (Table 2), we propose a practical diagnostic algorithm [4-6, 19, 22, 38, 39, 45, 64-66]. We suggest that an initial laboratory work-up should include a complete blood count, erythrocyte sedimentation rate, $\mathrm{C}$-reactive protein, antistreptolysin $\mathrm{O}$ titer, throat swab culture, and chest radiography. A pregnancy test must be done in all women of child-bearing age. A sputum acid-fast bacilli smear, mycobacterial culture, and tuberculin skin test or interferon- $\gamma$ release assay must be performed in the TB endemic regions and with abnormal chest $\mathrm{x}$-rays. If diarrhea, abdominal pain, or other gastrointestinal discomfort is present, a stool examination, culture, and coproparasitoscopic stool study must be performed. Mert et al. reported that leukocytosis, an elevated C-reactive protein level, an accelerated erythrocyte sedimentation rate, the presence of prolonged fever, cough, sore throat, diarrhea, arthritis, nonrelapsing EN, and an abnormal chest x-ray were predictors of secondary EN, while recurrent EN predicted primary EN $[5,19]$.

If the initial work-up is inconclusive, further laboratory testing and imaging studies should be performed. No test abnormalities specific to EN have been described. Unfortunately, in most cases, no specific etiology can be found; therefore, these patients are considered as idiopathic or primary EN.

\section{Differential Diagnoses}

Differential diagnoses are summarized in Table 3. The main differential diagnoses are erythema induratum of Bazin, superficial thrombophlebitis, and other forms of panniculitis. Histopathology is essential for diagnoses of greater precision.

\section{Treatment}

Therapy options are summarized in Table 4. Symptomatic support is an adequate approach for most patients. Compression bandages and limb elevation may be used for edema and pain relief [67]. Non-steroidal 


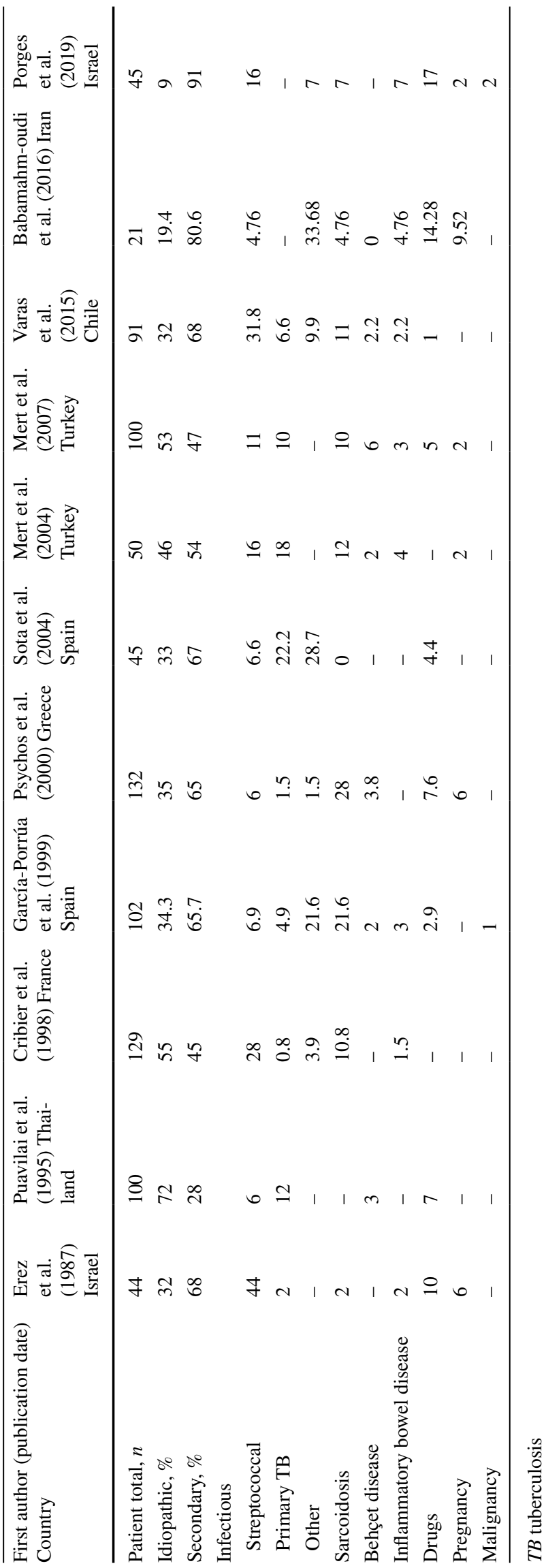


Table 3 Differential diagnoses of EN [93, 94, 95]

\begin{tabular}{|c|c|}
\hline Differential diagnosis & Comments \\
\hline Erythema induratum of Bazin & $\begin{array}{l}\text { Lobular panniculitis mainly associated with tuberculosis. Subcutaneous painful erythematous nodules, usu- } \\
\text { ally located on the back of the legs, prone to necrotic ulceration and scarring }\end{array}$ \\
\hline Superficial thrombophlebitis & $\begin{array}{l}\text { Usually presents with tenderness, local pain, induration, and erythema along the course of a superficial vein. } \\
\text { A palpable nodular cord might be present because of a thrombus in the affected vein }\end{array}$ \\
\hline Cutaneous polyarteritis nodosa & $\begin{array}{l}\text { Medium-sized artery vasculitis. Painful subcutaneous nodules, livedo reticularis and/or ulcers usually } \\
\text { located on the lower extremities. Mild systemic symptoms can be present }\end{array}$ \\
\hline Panniculitis-like T cell lymphoma & $\begin{array}{l}\text { Solitary or multiple nodules or plaques primarily on the extremities and the trunk. As the nodules and } \\
\text { plaques resolve, they may be replaced by areas of lipoatrophy. Systemic symptoms can be present }\end{array}$ \\
\hline EN leprosum & $\begin{array}{l}\text { Type } 2 \text { leprosy reactional state. Erythematous inflamed nodules and papules that may be superficial, mainly } \\
\text { affects the face and the extremities. Systemic symptoms can be present }\end{array}$ \\
\hline Pancreatic panniculitis & $\begin{array}{l}\text { Subcutaneous nodules on the legs, but also on the thorax, abdomen, arms, and scalp. The nodules can } \\
\text { become fluctuant and ulcerate, draining an oily material. Associated with pancreatic disorders }\end{array}$ \\
\hline Alpha-1 antitrypsin deficiency & $\begin{array}{l}\text { Subcutaneous, erythematous-purpuric, tender nodules or plaques that can ulcerate and drain. Usually affects } \\
\text { the lower trunk and proximal extremities. Heals with scarring and atrophy. Can be associated with emphy- } \\
\text { sema or hepatic dysfunction }\end{array}$ \\
\hline Lupus panniculitis & $\begin{array}{l}\text { Subcutaneous tender nodules and plaques located on the face, arms, shoulders, hips, buttocks, breasts, and } \\
\text { trunk }\end{array}$ \\
\hline
\end{tabular}

$E N$ erythema nodosum

anti-inflammatory drugs, such as indomethacin at $100-150 \mathrm{mg} /$ day or naproxen $500 \mathrm{mg} /$ day, may be used for pain control $[68,69]$. Caution should be taken with the use of non-steroidal anti-inflammatory drugs in patients with IBD as these drugs may worsen IBD symptoms [70].

In refractory disease, oral potassium iodide may be used with a dose of 300-900 mg daily divided into three doses and tapered to $150 \mathrm{mg} /$ day [71, 72]. Although it has been used for a long time with a good response rate [73, 74], a recent study showed low improvement and suggested that its potential efficacy in inflammatory skin disorders is overestimated [72]. The exact mechanism by which potassium iodide exerts its anti-inflammatory effect is unknown. The anti-inflammatory effects are due to increases in IL-10 and IL-35 levels [75] and the suppression of chemotaxis in neutrophils and their capability to generate toxic radicals [76]. Common acute side effects are diarrhea, nausea, vomiting, and stomach pain. Symptoms of iodism or potassium toxicity may appear with prolonged use. It is contraindicated during pregnancy or while breastfeeding [77].

Colchicine at 1-2 mg/day, adjusted to body weight, has been used mainly in patients with EN and Behçet disease [78-80]. It decreases neutrophil chemotaxis and degranulation. Common side effects are gastrointestinal symptoms (diarrhea, abdominal pain, and nausea) [81].

Dapsone inhibits neutrophil myeloperoxidase and neutrophil chemotaxis. Doses of 50-75 mg/day have been used with caution because of its potential side effects, including methemoglobinemia, hemolysis, agranulocytosis, and peripheral motor neuropathy [82]. Potassium iodide, colchicine, and dapsone are drugs used for treating neutrophilic dermatosis, making them a good option for EN associated with Bechet disease.

Systemic and intralesional corticosteroids are rarely used to treat EN. Prednisone $40 \mathrm{mg} /$ day has been used in severe conditions. For recalcitrant nodules, intralesional triamcinolone acetonide $5 \mathrm{mg} / \mathrm{mL}$, injected to the center of an inflamed lesion, has been used. An underlying infection or malignancy should be ruled out before using corticosteroids [10].

Some patients respond to hydroxychloroquine $200 \mathrm{mg}$ twice daily $[83,84]$. Tetracyclines, such as minocycline $100 \mathrm{mg}$ twice daily and tetracycline $500 \mathrm{mg}$ every 6-12 h, have been considered as an option for chronic EN $[85,86]$. Tumor necrosis factor- $\alpha$ inhibitors such as etanercept [87, 88], adalimumab [89, 90], and infliximab [91, 92] have been used in patients with recalcitrant disease. Thalidomide and cyclosporine A have been used in EN associated with IBD [9, 28].

\section{Prognosis}

The prognosis of EN is usually excellent with spontaneous resolution of the lesions in most patients. However, when an underlying condition is identified, it should be treated, and if a drug has been identified as a trigger, it should be withdrawn when feasible. 
Table 4 Treatment of erythema nodosum

\begin{tabular}{|c|c|c|c|}
\hline Treatment & Mechanism of action & Dosage & $\begin{array}{l}\text { Comments/pregnancy risk category }{ }^{\mathrm{a}} \\
{[96]}\end{array}$ \\
\hline $\begin{array}{l}\text { Compression bandage and limb } \\
\text { elevation [67] }\end{array}$ & Edema and pain relief & & \\
\hline $\begin{array}{l}\text { Nonsteroidal anti-inflammatory } \\
\text { drugs }\end{array}$ & Anti-inflammatory & & \multirow{3}{*}{$\begin{array}{l}\text { Caution in patients with IBD as they } \\
\text { may trigger a flare-up or worsen } \\
\text { an ongoing acute disease episode } \\
\text { Pregnancy category C }\end{array}$} \\
\hline Indomethacin [68] & & $100-150 \mathrm{mg}$ daily & \\
\hline Naproxen $[19,69]$ & & 500-1000 mg daily & \\
\hline Potassium iodide $[71,72,74,97]$ & $\begin{array}{l}\text { Anti-inflammatory, neutrophil } \\
\text { chemotaxis and suppression of } \\
\text { toxic radicals }\end{array}$ & 300-900 mg daily & $\begin{array}{l}\text { Use with caution in patients with } \\
\text { thyroid diseases } \\
\text { Pregnancy category D }\end{array}$ \\
\hline Colchicine $[78,79,80]$ & $\begin{array}{l}\text { Anti-inflammatory, decreases } \\
\text { neutrophil chemotaxis and } \\
\text { degranulation }\end{array}$ & $1-2 \mathrm{mg}$ daily & $\begin{array}{l}\text { Consider in patients with Behçet } \\
\text { syndrome } \\
\text { Pregnancy category C }\end{array}$ \\
\hline Dapsone [82] & $\begin{array}{l}\text { Anti-inflammatory, inhibits } \\
\text { neutrophil myeloperoxidase and } \\
\text { chemotaxis }\end{array}$ & $50-75 \mathrm{mg}$ daily & $\begin{array}{l}\text { Consider in recurrent and recalci- } \\
\text { trant lesions } \\
\text { Consider G6PD deficiency screen- } \\
\text { ing } \\
\text { Pregnancy category C }\end{array}$ \\
\hline Hydroxychloroquine $[83,84]$ & Anti-inflammatory & $200 \mathrm{mg}$ twice daily & $\begin{array}{l}\text { Consider in chronic and recurrent } \\
\text { cases } \\
\text { Pregnancy category C (not formal) }\end{array}$ \\
\hline $\begin{array}{l}\text { Intralesional corticosteroids } \\
\text { Triamcinolone acetonide [10] }\end{array}$ & Anti-inflammatory & $5 \mathrm{mg} / \mathrm{mL}$ & $\begin{array}{l}\text { Consider in recalcitrant nodules } \\
\text { Pregnancy category } \mathrm{C}\end{array}$ \\
\hline $\begin{array}{l}\text { Oral corticosteroids } \\
\text { Prednisone [10] }\end{array}$ & Anti-inflammatory & 40-60 mg daily & $\begin{array}{l}\text { Consider in severe disease Exclude } \\
\text { an underlying infectious etiology } \\
\text { before its use } \\
\text { Pregnancy category D in first } \\
\text { trimester, C in second and third } \\
\text { trimester }\end{array}$ \\
\hline $\begin{array}{l}\text { Tetracyclines } \\
\text { Minocycline [85] } \\
\text { Tetracycline [86] }\end{array}$ & $\begin{array}{l}\text { Anti-inflammatory; suppresses leu- } \\
\text { kocyte chemotaxis and reactive } \\
\text { oxygen species }\end{array}$ & $\begin{array}{l}100 \mathrm{mg} \text { twice daily } \\
500 \mathrm{mg} \text { twice to four times daily }\end{array}$ & $\begin{array}{l}\text { Consider for recalcitrant lesions } \\
\text { Pregnancy category D }\end{array}$ \\
\hline Erythromycin [98] & Anti-inflammatory & $500 \mathrm{mg}$ four times daily & $\begin{array}{l}\text { Consider for recalcitrant lesions } \\
\text { Pregnancy category B }\end{array}$ \\
\hline $\begin{array}{l}\text { TNF- } \alpha \text { inhibitors } \\
\text { Etanercept }[87,88]\end{array}$ & $\begin{array}{l}\text { Anti-inflammatory, } \\
\text { inhibits TNF- } \alpha\end{array}$ & $\begin{array}{l}25-50 \mathrm{mg} \text { twice weekly tapering } \\
\text { to } 25-50 \mathrm{mg} \text { weekly }\end{array}$ & $\begin{array}{l}\text { Screen for latent tuberculosis, HBV, } \\
\mathrm{HCV} \text {, and HIV infection before } \\
\text { use }\end{array}$ \\
\hline $\begin{array}{l}\text { Adalimumab }[89,90] \\
\text { Infliximab }[91,92]\end{array}$ & & $\begin{array}{l}40 \mathrm{mg} \text { every } 2 \text { weeks } \\
5 \mathrm{mg} / \mathrm{kg} \text { in weeks } 0,2 \text {, and } 6\end{array}$ & $\begin{array}{l}\text { Consider in patients with IBD } \\
\text { Pregnancy category B }\end{array}$ \\
\hline Thalidomide [9] & $\begin{array}{l}\text { Anti-inflammatory, thought to be } \\
\text { through inhibition of TNF- } \alpha \\
\text { release and activity }\end{array}$ & No specific data & $\begin{array}{l}\text { Consider in patients with IBD } \\
\text { Pregnancy category X }\end{array}$ \\
\hline Cyclosporine A [9] & & No specific data & $\begin{array}{l}\text { Consider in patients with IBD } \\
\text { Pregnancy category C }\end{array}$ \\
\hline
\end{tabular}

G6PD glucose-6-phosphate dehydrogenase, $H B V$ hepatitis B virus, $H C V$ hepatitis $\mathrm{C}$ virus, $H I V$ human immunodeficiency virus, $I B D$ inflammatory bowel disease, $T N F$ tumor necrosis factor

${ }^{a}$ Former US Food and Drug Administration pregnancy risk category

\section{Conclusions}

Although a large percentage of patients with EN have an unknown etiology, it can be the first sign of a systemic disease in some patients. An early diagnosis is important for optimal management of the underlying disease; thus, a detailed medical history, physical examination, laboratory tests, and imaging studies should be performed during the initial work-up. The diagnostic algorithm for EN described in this study is intended to help physicians make 
a timely and accurate diagnosis of the underlying cause, which could be a potentially life-threatening condition, and to determine an optimal treatment strategy.

\section{Declarations}

Funding No sources of funding were received for the preparation of this article.

Conflicts of interest/competing interests Daniela Michelle PérezGarza, Sonia Chavez-Alvarez, Jorge Ocampo-Candiani, and Minerva Gomez-Flores have no conflicts of interest that are directly relevant to the content of this article.

Ethics approval Not applicable.

Consent to participate Not applicable.

Consent for publication Patients signed an informed consent regarding the publication of their data and photographs.

Availability of data and material Not applicable.

Code availability Not applicable.

Authors' contributions All authors made substantial contributions to the conception and design of the work; drafted the work or revised it critically for important intellectual content; and approved the version to be published.

\section{References}

1. Molina-Ruiz AM, Requena L. Erythema nodosum. Med Clin (Barc). 2016;147(2):81-6. https://doi.org/10.1016/j.medcl i.2016.03.038.

2. Willan R. On cutaneous diseases, vol. 1. London: J. Johnson; 1808.

3. Franzen C. Leopold Mozart and the first description of erythema nodosum. Arch Dermatol. 2008;144(8):1049-50. https://doi. org/10.1001/archderm.144.8.1049.

4. Garcia-Porrua C, Gonzalez-Gay MA, Vazquez-Caruncho M, Lopez-Lazaro L, Lueiro M, Fernandez ML, et al. Erythema nodosum: etiologic and predictive factors in a defined population. Arthritis Rheum. 2000;43(3):584-92. https://doi. org/10.1002/1529-0131(200003)43:3\%3c584:AID-ANR 15 \%3e3.0.CO;2-6.

5. Mert A, Ozaras R, Tabak F, Pekmezci S, Demirkesen C, Ozturk R. Erythema nodosum: an experience of 10 years. Scand J Infect Dis. 2004;36(6-7):424-7. https://doi.org/10.1080/003655404100271 84.

6. Cribier B, Caille A, Heid E, Grosshans E. Erythema nodosum and associated diseases: a study of 129 cases. Int J Dermatol. 1998;37(9):667-72. https://doi.org/10.104 6/j.1365-4362.1998.00316.x.

7. Kakourou T, Drosatou P, Psychou F, Aroni K, Nicolaidou P. Erythema nodosum in children: a prospective study. J Am Acad Dermatol. 2001;44(1):17-21. https://doi.org/10.1067/mjd.2001.11087 7.

8. Bohn S, Buchner S, Itin P. [Erythema nodosum: 112 cases. Epidemiology, clinical aspects and histopathology]. Schweiz Med Wochenschr. 1997;127(27-28):1168-76.
9. Schwartz RA, Nervi SJ. Erythema nodosum: a sign of systemic disease. Am Fam Physician. 2007;75(5):695-700.

10. Requena L, Sanchez Yus E. Erythema nodosum. Semin Cutan Med Surg. 2007;26(2):114-25. https://doi.org/10.1016/j. sder.2007.02.009.

11. Jones JV, Cumming RH, Asplin CM. Evidence for circulating immune complexes in erythema nodosum and early sarcoidosis. Ann N Y Acad Sci. 1976;278:212-9. https://doi. org/10.1111/j.1749-6632.1976.tb47032.x.

12. Akdis AC, Kilicturgay K, Helvaci S, Mistik R, Oral B. Immunological evaluation of erythema nodosum in tularaemia. Br J Dermatol. 1993;129(3):275-9. https://doi. org/10.1111/j.1365-2133.1993.tb11846.x.

13. Nunnery E, Persellin RH, Pope RM. Lack of circulating immune complexes in uncomplicated erythema nodosum. J Rheumatol. 1983;10(6):991-4.

14. Demirkesen C, Tuzuner N, Senocak M, Turkmen I, Aki H, Kepil $\mathrm{N}$, et al. Comparative study of adhesion molecule expression in nodular lesions of Behcet syndrome and other forms of panniculitis. Am J Clin Pathol. 2008;130(1):28-33. https://doi. org/10.1309/3 YJG2AWU06H0NX8G.

15. Kunz M, Beutel S, Brocker E. Leucocyte activation in erythema nodosum. Clin Exp Dermatol. 1999;24(5):396-401. https://doi. org/10.1046/j.1365-2230.1999.00511.x.

16. De Simone C, Caldarola G, Scaldaferri F, Petito V, Perino F, Arena V, et al. Clinical, histopathological, and immunological evaluation of a series of patients with erythema nodosum. Int J Dermatol. 2016;55(5):e289-94. https://doi.org/10.1111/ ijd.13212.

17. Mana J, Marcoval J. Erythema nodosum. Clin Dermatol. 2007;25(3):288-94. https://doi.org/10.1016/j.clindermat ol.2007.03.006.

18. Favour CB. Systemic manifestations of erythema nodosum. Calif Med. 1956;85(4):207-12.

19. Mert A, Kumbasar H, Ozaras R, Erten S, Tasli L, Tabak F, et al. Erythema nodosum: an evaluation of 100 cases. Clin Exp Rheumatol. 2007;25(4):563-70.

20. Forstrom L, Winkelmann RK. Acute panniculitis: a clinical and histopathologic study of 34 cases. Arch Dermatol. 1977;113(7):909-17.

21. Thurber S, Kohler S. Histopathologic spectrum of erythema nodosum. J Cutan Pathol. 2006;33(1):18-26. https://doi.org/10 $.1111 / \mathrm{j} .0303-6987.2006 .00402 . x$.

22. Puavilai S, Sakuntabhai A, Sriprachaya-Anunt S, Rajatanavin N, Charuwichitratana S. Etiology of erythema nodosum. J Med Assoc Thai. 1995;78(2):72-5.

23. Alpsoy E, Donmez L, Onder M, Gunasti S, Usta A, Karincaoglu $\mathrm{Y}$, et al. Clinical features and natural course of Behcet's disease in 661 cases: a multicentre study. Br J Dermatol. 2007;157(5):901-6. https://doi.org/10.1111/j.1365-2133.2007.08116.x.

24. Esatoglu SN, Kutlubay Z, Ucar D, Hatemi I, Uygunoglu U, Siva A, et al. Behcet's syndrome: providing integrated care. J Multidiscip Healthc. 2017;10:309-19. https://doi.org/10.2147/JMDH. S93681.

25. Misago N, Tada Y, Koarada S, Narisawa Y. Erythema nodosumlike lesions in Behcet's disease: a clinicopathological study of 26 cases. Acta Derm Venereol. 2012;92(6):681-6. https://doi. org/10.2340/00015555-1349.

26. Bernstein $\mathrm{CN}$, Blanchard JF, Rawsthorne P, Yu N. The prevalence of extraintestinal diseases in inflammatory bowel disease: a population-based study. Am J Gastroenterol. 2001;96(4):1116-22. https://doi.org/10.1111/j.1572-0241.2001.03756.x.

27. Huang BL, Chandra S, Shih DQ. Skin manifestations of inflammatory bowel disease. Front Physiol. 2012;3:13. https://doi. org/10.3389/fphys.2012.00013. 
28. Chavez-Alvarez S, Gomez-Flores M, Ocampo-Candiani J. Cutaneous manifestations in inflammatory bowel disease. Gac Med Mex. 2016;152(5):622-30.

29. Monsen U, Sorstad J, Hellers G, Johansson C. Extracolonic diagnoses in ulcerative colitis: an epidemiological study. Am J Gastroenterol. 1990;85(6):711-6.

30. Mir-Madjlessi SH, Taylor JS, Farmer RG. Clinical course and evolution of erythema nodosum and pyoderma gangrenosum in chronic ulcerative colitis: a study of 42 patients. Am J Gastroenterol. 1985;80(8):615-20.

31. Yanardag H, Pamuk ON, Karayel T. Cutaneous involvement in sarcoidosis: analysis of the features in 170 patients. Respir Med. 2003;97(8):978-82. https://doi.org/10.1016/s0954 $-6111(03) 00127-6$.

32. Jain R, Yadav D, Puranik N, Guleria R, Jin JO. Sarcoidosis: causes, diagnosis, clinical features, and treatments. J Clin Med. 2020;9(4):1081. https://doi.org/10.3390/jcm9041081.

33. Shulman ST, Bisno AL, Clegg HW, Gerber MA, Kaplan EL, Lee $\mathrm{G}$, et al. Clinical practice guideline for the diagnosis and management of group A streptococcal pharyngitis: 2012 update by the Infectious Diseases Society of America. Clin Infect Dis. 2012;55(10):e86-102. https://doi.org/10.1093/cid/cis629.

34. Hahn RG, Knox LM, Forman TA. Evaluation of poststreptococcal illness. Am Fam Physician. 2005;71(10):1949-54.

35. Chen S, Chen J, Chen L, Zhang Q, Luo X, Zhang W. Mycobacterium tuberculosis infection is associated with the development of erythema nodosum and nodular vasculitis. PLoS One. 2013;8(5):e62653. https://doi.org/10.1371/journal.pone.00626 53.

36. Bjorn-Mortensen K, Ladefoged K, Simonsen J, Michelsen SW, Sorensen HC, Koch A, et al. Erythema nodosum and the risk of tuberculosis in a high incidence setting. Int J Circumpolar Health. 2016;75:32666. https://doi.org/10.3402/ijch.v75.32666.

37. Mert A, Ozaras R, Tabak F, Ozturk R. Primary tuberculosis cases presenting with erythema nodosum. J Dermatol. 2004;31(1):66-8. https://doi.org/10.1111/j.1346-8138.2004.tb00509.x.

38. Varas P, Antunez-Lay A, Bernucci JM, Cossio L, Gonzalez S, Eymin G. Erythema nodosum: analysis of 91 hospitalized patients. Rev Med Chil. 2016;144(2):162-8. https://doi.org/10.4067/S0034 $-98872016000200003$.

39. Sota Busselo I, Onate Vergara E, Perez-Yarza EG, Lopez Palma F, Ruiz Benito A, Albisu Andrade Y. Erythema nodosum: etiological changes in the last two decades. An Pediatr (Barc). 2004;61(5):403-7. https://doi.org/10.1016/s1695-4033(04)78414 $-3$.

40. DiCaudo DJ. Coccidioidomycosis: a review and update. J Am Acad Dermatol. 2006;55(6):929-42; quiz 43-5. https://doi. org/10.1016/j.jaad.2006.04.039.

41. Khaliq MF, Mohamed HE. Blastomycosis presenting as erythema nodosum. Fungal infection case reports. Thoracic Society International Conference; 17-22 May 2019; Dallas (TX).

42. Body BA. Cutaneous manifestations of systemic mycoses. Dermatol Clin. 1996;14(1):125-35. https://doi.org/10.1016/s0733 -8635(05)70332-6.

43. Ordieres-Ortega L, Toledo-Samaniego N, Parra-Virto A, Fernandez-Carracedo E, Lavilla-Olleros C, Demelo-Rodriguez P. Atypical erythema nodosum in a patient with COVID-19 pneumonia. Dermatol Ther. 2020;33(4):e13658. https://doi.org/10.1111/ dth. 13658 .

44. Suter P, Mooser B, Pham Huu Thien HP. Erythema nodosum as a cutaneous manifestation of COVID-19 infection. BMJ Case Rep. 2020;13(7):e236613. https://doi.org/10.1136/bcr-2020-236613.

45. Psychos DN, Voulgari PV, Skopouli FN, Drosos AA, Moutsopoulos HM. Erythema nodosum: the underlying conditions. Clin Rheumatol. 2000;19(3):212-6. https://doi.org/10.1007/s1006 70050159 .
46. Cohen PR. Combined reduced-antigen content tetanus, diphtheria, and acellular pertussis (tdap) vaccine-related erythema nodosum: case report and review of vaccine-associated erythema nodosum. Dermatol Ther (Heidelb). 2013;3(2):191-7. https://doi.org/10.1007/s13555-013-0035-9.

47. Kim YJ, Cohen PR. Anastrozole-induced dermatitis: report of a woman with an anastrozole-associated dermatosis and a review of aromatase inhibitor-related cutaneous adverse events. Dermatol Ther (Heidelb). 2020;10(1):221-9. https://doi.org/10.1007/ s13555-020-00353-3.

48. Jhaveri K, Halperin P, Shin SJ, Vahdat L. Erythema nodosum secondary to aromatase inhibitor use in breast cancer patients: case reports and review of the literature. Breast Cancer Res Treat. 2007;106(3):315-8. https://doi.org/10.1007/s1054 9-007-9518-7.

49. Pileckyte M, Griniute R. Erythema nodosum association with malignant lymphoma. Medicina (Kaunas). 2003;39(5):438-42.

50. Bonci A, Di Lernia V, Merli F, Lo Scocco G. Erythema nodosum and Hodgkin's disease. Clin Exp Dermatol. 2001;26(5):408-11. https://doi.org/10.1046/j.1365-2230.2001.00847.x.

51. Samara Y, Thomas J, Dasanu CA. Paraneoplastic erythema nodosum as a prelude to Hodgkin lymphoma. Conn Med. 2017;81(3):157-60.

52. Xu X, Liang G, Duan M, Zhang L. Acute myeloid leukemia presenting as erythema nodosum: a case report. Medicine (Baltimore). 2017;96(47):e8666. https://doi.org/10.1097/MD.00000 00000008666.

53. Perez NB, Bernad B, Narvaez J, Valverde J. Erythema nodosum and lung cancer. Joint Bone Spine. 2006;73(3):336-7. https:// doi.org/10.1016/j.jbspin.2005.10.009.

54. Lillo A, Gil MJ, Jimenez R, Monferrer R. Erythema nodosum and adenocarcinoma of the colon. Med Clin (Barc). 1997;108(8):318.

55. Altomare GF, Capella GL. Paraneoplastic erythema nodosum in a patient with carcinoma of the uterine cervix. Br J Dermatol. 1995;132(4):667-8. https://doi.org/10.1111/j.1365-2133.1995. tb08732.x.

56. Glinkov S, Krasnaliev I, Atanassova M, Arnaudov P, Kirov K, Glinkova V. Hepatocellular carcinoma associated with paraneoplastic erythema nodosum and polyarthritis. J Hepatol. 2003;39(4):656-7. https://doi.org/10.1016/s0168-8278(03)00248 $-4$.

57. Virshup AM, Sliwinski AJ. Polyarthritis and subcutaneous nodules associated with carcinoma of the pancreas. Arthritis Rheum. 1973;16(3):388-92. https://doi.org/10.1002/art.1780160315.

58. Hamzaoui A, Gassab E, Kochteli I, Njim L, Klii R, Zakhama A, et al. Erythema nodosum revealing parathyroid carcinoma. Eur Ann Otorhinolaryngol Head Neck Dis. 2011;128(5):272-4. https ://doi.org/10.1016/j.anorl.2011.02.003.

59. Lin JT, Chen PM, Huang DF, Kwang WK, Lo K, Wang WS. Erythema nodosum associated with carcinoid tumour. Clin Exp Dermatol. 2004;29(4):426-7. https://doi.org/10.111 $1 / \mathrm{j} .1365-2230.2004 .01544 . x$.

60. Taillan B, Ferrari E, Fuzibet JG, Vinti H, Pesce A, Dujardin P. Erythema nodosum and Hodgkin's disease. Clin Rheumatol. 1990;9(3):397-8. https://doi.org/10.1007/BF02114402.

61. Fearfield LA, Bunker CB. Radiotherapy and erythema nodosum. Br J Dermatol. 2000;142(1):189. https://doi.org/10.104 6/j.1365-2133.2000.03274.x.

62. Takagawa S, Nakamura S, Yokozeki H, Nishioka K. Radiationinduced erythema nodosum. Br J Dermatol. 1999;140(2):372-3. https://doi.org/10.1046/j.1365-2133.1999.02688.x.

63. Moreau E, Peiffert D, Schmutz JL, Granel-Brocard F, Bursztejn AC. Sweet syndrome and erythema nodosum in a case of anal canal cancer during concomitant radiochemotherapy. Eur J Dermatol. 2019;29(5):539-40. https://doi.org/10.1684/ejd.2019.3628. 
64. Babamahmoudi F, Amuzgar A, Mousavi T, Davoodi L. Erythema nodosum: what should we consider about it? Caspian J Intern Med. 2016;7(4):304-5.

65. Porges T, Shafat T, Sagy I, Zeller L, Bartal C, Khutarniuk T, et al. Clinical, epidemiological, and etiological changes in erythema nodosum. Isr Med Assoc J. 2018;20(12):770-2.

66. Erez A, Horowitz J, Sukenik S. Erythema nodosum in the Negev area: a survey of 50 patients. Isr J Med Sci. 1987;23(12):1228-31.

67. Blake T, Manahan M, Rodins K. Erythema nodosum: a review of an uncommon panniculitis. Dermatol Online J. 2014;20(4):22376.

68. Mokhtari F, Abtahi-Naeini B, Pourazizi M. Erythema nodosum migrans successfully treated with indomethacin: a rare entity. Adv Biomed Res. 2014;3:264. https://doi.org/10.4103/22779175.148243.

69. Lehman CW. Control of chronic erythema nodosum with naproxen. Cutis. 1980;26(1):66-7.

70. Lamb CA, Kennedy NA, Raine T, Hendy PA, Smith PJ, Limdi JK, et al. British Society of Gastroenterology consensus guidelines on the management of inflammatory bowel disease in adults. Gut. 2019;68(Suppl 3):s1-106. https://doi.org/10.1136/gutjnl-2019318484.

71. Sawada H, Kanehisa F, Katoh N, Asai J. Potassium iodide in successful treatment of erythema nodosum-like lesions induced by combination therapy with dabrafenib and trametinib. J Dermatol. 2020;47(1):e7-8. https://doi.org/10.1111/1346-8138.15108.

72. Anzengruber F, Mergenthaler C, Murer C, Dummer R. Potassium iodide for cutaneous inflammatory disorders: a monocentric, retrospective study. Dermatology. 2019;235(2):137-43. https://doi. org/10.1159/000494614.

73. Horio T, Danno K, Okamoto H, Miyachi Y, Furukawa F, Imamura S. Treatment of erythematous dermatoses with potassium iodide. J Dermatol. 1981;8(6):499-505. https://doi. org/10.1111/j.1346-8138.1981.tb02568.x.

74. Schulz EJ, Whiting DA. Treatment of erythema nodosum and nodular vasculitis with potassium iodide. Br J Dermatol. 1976;94(1):75-8. https://doi.org/10.1111/j.1365-2133.1976.tb043 45.x.

75. Hayashi S, Ishikawa S, Ishii E, Koike M, Kaminaga T, Hamasaki Y, et al. Anti-inflammatory effects of potassium iodide on SDS-induced murine skin inflammation. J Invest Dermatol. 2020;140(10):2001-8. https://doi.org/10.1016/j.jid.2020.01.028.

76. Sterling JB, Heymann WR. Potassium iodide in dermatology: a 19th century drug for the 21 st century-uses, pharmacology, adverse effects, and contraindications. J Am Acad Dermatol. 2000;43(4):691-7. https://doi.org/10.1067/mjd.2000.107247.

77. Costa RO, Macedo PM, Carvalhal A, Bernardes-Engemann AR. Use of potassium iodide in dermatology: updates on an old drug. An Bras Dermatol. 2013;88(3):396-402. https://doi.org/10.1590/ abd1806-4841.20132377.

78. Wallace SL. Erythema nodosum treatment with colchicine. JAMA. 1967;202(11):1056.

79. Yurdakul S, Mat C, Tuzun Y, Ozyazgan Y, Hamuryudan V, Uysal O, et al. A double-blind trial of colchicine in Behcet's syndrome. Arthritis Rheum. 2001;44(11):2686-92. https:// doi.org/10.1002/1529-0131(200111)44:11\%3c2686:aid-art44 8\%3e3.0.co;2-h.

80. De Coninck P, Baclet JL, Di Bernardo C, Buschges B, Plouvier B. Treatment of erythema nodosum with colchicine. Presse Med. 1984;13(11):680.

81. Stewart S, Yang KCK, Atkins K, Dalbeth N, Robinson PC. Adverse events during oral colchicine use: a systematic review and meta-analysis of randomised controlled trials. Arthritis Res Ther. 2020;22(1):28. https://doi.org/10.1186/s13075-020-2120-7.

82. Song JS, Halim K, Vleugels RA, Merola JF. Dapsone for treatment of erythema nodosum. Dermatol Online J. 2016;22(2):13030/ qt8z782742.

83. Jarrett $\mathrm{P}$, Goodfield MJ. Hydroxychloroquine and chronic erythema nodosum. Br J Dermatol. 1996;134(2):373. https://doi. org/10.1111/j.1365-2133.1996.tb07635.x.

84. Alloway JA, Franks LK. Hydroxychloroquine in the treatment of chronic erythema nodosum. Br J Dermatol. 1995;132(4):661-2. https://doi.org/10.1111/j.1365-2133.1995.tb08725.x.

85. Davis MD. Response of recalcitrant erythema nodosum to tetracyclines. J Am Acad Dermatol. 2011;64(6):1211-2. https://doi. org/10.1016/j.jaad.2009.10.008.

86. Rohatgi S, Basavaraj KH, Ashwini PK, Kanthraj GR. Role of tetracycline in recalcitrant erythema nodosum. Indian Dermatol Online J. 2014;5(3):314-5. https://doi.org/10.4103/22295178.137787.

87. Boyd AS. Etanercept treatment of erythema nodosum. Skinmed. 2007;6(4):197-9. https://doi.org/10.1111/j.1540-9740.2007.05882 .x.

88. Alia E, Varma A, Brody J, Keyzner A, Singh R, Levitt J. Use of etanercept in management of tyrosine kinase-inhibitor-induced erythema nodosum. JAAD Case Rep. 2020;6(6):567-8. https:// doi.org/10.1016/j.jdcr.2020.04.016.

89. Benitez-Gutierrez L, Tutor-de Ureta P, Mellor-Pita S, YebraBango M. Refractory chronic erythema nodosum treated with adalimumab. Rev Clin Esp (Barc). 2013;213(9):466-7. https:// doi.org/10.1016/j.rce.2013.08.007.

90. Callejas Rubio JL, Rios Fernandez R, Sanchez Cano D, Ortego Centeno N. Adalimumab in the treatment of erythema nudosum. Med Clin (Barc). 2010;135(2):90. https://doi.org/10.1016/j.medcl i.2009.03.028.

91. Clayton TH, Walker BP, Stables GI. Treatment of chronic erythema nodosum with infliximab. Clin Exp Dermatol. 2006;31(6):823-4. https://doi.org/10.1111/j.1365-2230.2006.02221.x.

92. Vanbiervliet G, Anty R, Schneider S, Arab K, Rampal P, Hebuterne X. Sweet's syndrome and erythema nodosum associated with Crohn's disease treated by infliximab. Gastroenterol Clin Biol. 2002;26(3):295-7.

93. Castellano Cuesta J, Velasco Pastor M, Fernández-Llanio Comella $\mathrm{N}$, et al. Eritema nudoso y otras paniculitis. In: Belmonte Serrano MA, Castellano Cuesta JA, Román Ivorra JA, Rosas Gomez de Salazar JC, editors., et al., Enfermedades Reumáticas. 2nd ed. Valencia, Spain: Ibález \& Plaza Asociados S.L; 2013. p. 679-705.

94. Wick MR. Panniculitis: a summary. Semin Diagn Pathol. 2017;34(3):261-72.

95. Patterson JW, Requena L. Paniculitis. In: Bolognia JL, Schaffer JV, Cerroni L, editors. Dermatology. 2. 4th ed. Elsevier; 2019. p. 1733-57.

96. Alexandra Acosta K, Haver MC, Kelly B. Etiology and therapeutic management of erythema nodosum during pregnancy: an update. Am J Clin Dermatol. 2013;14(3):215-22.

97. Horio T, Danno K, Okamoto H, Miyachi Y, Imamura S. Potassium iodide in erythema nodosum and other erythematousdermatoses. J Am Acad Dermatol. 1983;9(1):77-81.

98. Kaya TI, Tursen U, Baz K, Ikizoglu G, Dusmez D. Severe erythema nodosum due to Behçet's disease responsive to erythromycin. J Dermatol Treat. 2009;14(2):124-7. 